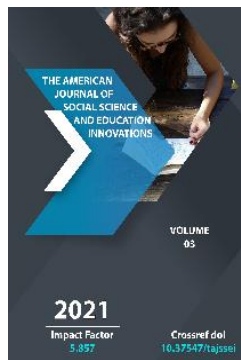

\title{
On The Study Of Ancient Irrigation Systems In Central Asia
}

\author{
Alisher Akhmadjonovich Alokhunov \\ PhD, Senior Lecturer, Department Of World History, Fergana State University Fergana, \\ Uzbekistan
}

Journal Website:

http://usajournalshub.c

om/index,php/tajssei

Copyright: Original

content from this work

may be used under the

terms of the creative

commons attributes

4.0 licence.

\section{ABSTRACT}

In the climatic conditions of Central Asia, irrigation issues are a vital necessity and are considered decisive factors in socio-economic and political development. Over the centuries, the population has improved agriculture, gaining vast experience in the efficient use of land and water, creating a kind of school in this area. The article analyzes some reflections on the development of the irrigation system, scientific study and historical analysis of this topic.

\section{KEYWORDS}

Irrigation, irrigation facilities, water sources, irrigation networks, development of desert and virgin lands, natural and climatic conditions, irrigated farming culture.

\section{INTRODUCTION}

As a result of historical and archeologicalethnographic research, fundamental works, scientific collections on the peculiarities, condition, technical tools of ancient irrigation, agriculture and farming culture have been created. Scholars dealing with the history of irrigation and its archeological sources have focused primarily on the socio-economic, 
political aspects and consequences of the issue. The genesis of the origin of the Asian style in production is also interpreted and scientifically substantiated by scientists in connection with the first, developed artificial irrigation system in the Middle East. Because artificial irrigation was an objective necessity. In the climatic conditions of Central Asia, the problem of irrigation has become a vital necessity, a decisive factor in socio-economic and socio-political life, development.

It is very important to scientifically analyze the socio-economic development of peoples at different stages of history and the development of productive forces, the peculiarities of economic culture, the stages of formation and development of irrigated agriculture and related urban processes. Particular emphasis is placed on the factual study of the history of irrigation systems and the history of irrigated agriculture on the basis of theoretical and conceptual approaches [6, 5].

\section{MATERIALS AND METHODS}

Irrigation As in all other countries of the East, the nature of Uzbekistan - the climatic conditions of the soil - requires farming through canals and waterworks. Therefore, the emergence of an ancient agricultural culture in the river valleys and oases of our Motherland, the construction of irrigation networks and waterworks were closely linked with the development of irrigation. Archaeological excavations in the Khorezm oasis, Zarafshan, Fergana and Syrdarya valleys show that irrigation networks and agriculture based on it date back to the Bronze Age.

In the history of the development of irrigation in Central Asia, three main stages have been identified, the first stage of which is a period of considerable time (from the Neolithic period to the Late Bronze and Early Iron Ages). This period includes the study of the knowledge of the field of irrigation and the use of openirrigated agriculture, the inflow and outflow of small rivers, temporary flows, and the use of parts of riverbeds in the lowlands. Gradually, farmers began to move to new usable land areas by diverting excess water from floodplains to other, lower-lying areas, in addition to lands that had been flattened by flooding.

In the second millennium BC, the groundwork was laid for the birth of irrigated agriculture, that is, the transition from backward irrigation to backward irrigation.

\section{RESULT AND DISCUSSION}

The emergence of villages was associated with the development of an irrigated farming culture in the social division of labor. Irrigated agriculture was formerly carried out using natural water flow, and later developed on the basis of irrigation facilities (dams, canals, etc.) and means (streams). Of course, the creation, maintenance and use of such facilities, or in modern parlance, irrigation infrastructure, required the labor of the general public, the coexistence of the population. Thus, the community (sotsium), the territorial unity of the people, the settlements of a stable population emerged. As a result of the separation of irrigated agriculture from animal husbandry, and on this basis the development of handicrafts and trade, the next important stage of social and territorial division of labor began. Such changes in the life of society led to the separation and development of cities from villages. It was from this period that two forms of territorial organization of social life, namely villages and towns, emerged [9, 7]. 
The second phase began in the middle of the first millennium $B C$ with the invention of water distribution devices and main systems in the main rivers of Central Asia and the development of irrigation, which is characterized by extensive development of agricultural lands in the vast plains of Central Asia (Amudarya, Syrdarya, Zarafshan). Archaeological research in recent years has revealed that during this period a large state emerged in Central Asia, which played an important role in the economic, political and social life of its peoples.

The high development of the ancient irrigation networks dates back to antiquity (IV BC - I-IV centuries $A D$ ). Thanks to the successful development of irrigation facilities and irrigated agriculture in the major Central Asian river basins of antiquity, vast areas of land were irrigated and many new lands were developed, and many ancient cities emerged and opentype settlements were established.

In Central Asia, traces of ancient irrigation systems are well preserved on the ancient irrigated lands between the Amudarya and Syrdarya rivers.

The third stage of development of irrigation in Uzbekistan corresponds to the early and advanced period of the Middle Ages [10, 8-11].

In their centuries-old irrigation activities, the population has discovered and improved magnificent water structures, depending on the type and condition of water sources, as well as the size of the water balance, flow rate, and the natural conditions of the flowing areas. Consistent scientific study, historical analysis and research on this topic was initiated by the Russian scientist, academician V.V. Bartold. V.V. Bartold in his monograph "On the history of irrigation in Turkestan" summarizes and analyzes the written sources of the Middle Ages [2, 97-232]. This work is a unique study of the history of artificial irrigation and irrigation in Central Asia, which provides a very rich set of information about irrigation systems built in the Middle Ages, the material and technical means used in their construction, tools, methods and history of manual labor. Along with the geographical analysis of irrigation, the irrigation situation at that time was considered and generalized.

In his work, V.V. Bartold analyzes the medieval features of the economic life of the Central Asian oasis, a comprehensive study of its ancient irrigation networks, emphasizes its importance in illuminating the history of the peoples here, and emphasizes its practical significance for future periods.

Historians, orientalists, economists, and political figures who have lived and researched in the territory of modern Uzbekistan on the history and problems of artificial irrigation, agricultural culture, desert and reserve land development have also collected and written valuable scientific works. In particular, orientalists and archeologists: I.Petrushevsky (1960), V.Masson (1951), B.Latinin (1942; 1962), S.Tolstov (1948), Ya.Gulomov (1957), B.Andrianov (1969; 1984), B.Litvinskiy (1963), R.Aminova (1957), Zeymal (1971), A.Muhammadjonov (1972; 1978), S.Jalilov (1977), A.Abdulxamidov (1988), N.Ochilov (1991) ), The works of researchers such as K.Nasritdinov (1994; 2009) play an important role in the study of the history of artificial irrigation, agricultural culture and irrigation. The historical materials and conclusions analyzed scientifically in their works have expanded the opportunities for more in-depth scientific study of the history of irrigation, 
irrigation techniques, artificial irrigation, water use in Central Asia.

Academician S.P.Tolstov's archeological works are aimed at studying the sources and development of the irrigation system in the Khorezm oasis and the plains of Central Asia. started. He noted that the formation and development of the irrigation system in Central Asia, especially in the Khorezm oasis, based on a comprehensive analysis of historical sources on the historical dynamics of irrigation development, not only in connection with the catastrophic natural and climatic conditions, but also socio-political factors: destructive wars, political and economic crises, struggles to build a centralized power have also had an impact $[11 ; 12 ; 13 ; 14]$.

B.A.Latinin's books and scientific articles also play an important role in the study of the history of irrigation. He puts forward a number of ideas on the history of the creation and development of artificial irrigation systems and irrigation facilities in the Fergana Valley. B.A.Latinin divides the development of irrigation techniques in Central Asia into three main stages and analyzes their characteristic features $[7,9]$.

Minddendorf, a member of the St.Petersburg Academy who surveyed the Fergana Valley, wrote in 1878: "These irrigation works are of even greater surprise to us. The technically undeveloped people carried water over long distances along the mountains and valleys in the steep mountainous areas to their fields, and we are amazed that this work was done without any leveling knowledge or tools "[8, 23].

The works of some authors on irrigation in the Fergana Valley have also been published, such as the works of S.Jalilov [4], A.Abdulhamidov
[1]. In their works, they highlighted the irrigation of the valley, its unique aspects.

A new stage in the study of artificial irrigation systems and their socio-economic, historical and ethnographic features of the peoples living in ancient Khorezm and between the two rivers, engaged in agriculture and irrigation, was the creative work of the famous Uzbek archeologist, academician Ya.G.Gulyamov. related to activities. Yahyo Gulyamov's activity in the development of archeological science in Uzbekistan, preservation and protection of archeological monuments is described by the first President I.A.Karimov as the greatest courage $[5,166]$. A special chapter of the scientist's book "History of irrigation in Khorezm (from ancient times to the present)" is devoted to the study of historical and ethnographic aspects of the construction of irrigation hydrotechnical people, in which archeological materials and data are scientifically and theoretically generalized [3].

Summarizing the state and development of irrigation in ancient times, over the centuries, folk masters have built irrigation canals, irrigation systems, and created magnificent hydraulic structures without special scientific knowledge, knowledge of the laws of hydraulics, equipment and complex sophisticated weapons. They built the head of the canal to fit the local relief from the river and to supply water to the right or left side of the stream without artificial structures from the earthen stream along the flat slopes with the elevations sideways. Canals were also excavated from the river along the highest points of the site, the water was diverted to the distribution network on both sides, and the canals were passed through underground water galleries, tunnels ("perforated"), and sewers. 


\section{CONCLUSION}

In short, irrigation has been the greatest invention, survival and inexhaustible source of human, human and social development. The development of irrigation networks has served as a natural and social condition for the integration of people into socio-economic communities, the formation of settlements, villages, neighborhoods, large settlements. It is no coincidence that in the unique literary and artistic heritage of our people, the supply of water, the construction of waterworks is a symbol of heroism

\section{REFERENCES}

1. Абдулхамидов А. Орошение предгорьях Узбекистана. - Т.: Фан, 1990. - 175 с.

2. Бартольд В.В. К истории орошения Туркестана. Сочинения, т. III. - М.: Наука, 1965. - С. 97-232.

3. Ғуломов Я.Ғ. Хоразмнинг суғорилиш тарихи (Энг қадимги даврдан хозирги кунгача). ЎзССР ФА нашриёти. - Тошкент, 1959. - 3116.

4. Жалилов С. Фарғона водийсининг суғорилиш тарихидан (XIX аср - XX аср бошлари). - Т.: Фан, 1977.

5. Каримов И.А. Юксак маънавият енгилмас куч. - Т.: Маънавият, 2008. - 176 6.

6. Комилов О.К. Ўзбекистонда ирригация тизими ривожланиши ва унинг оқибатлари (1951-1990 йй.). Тарих фанлари доктори (Dsc) диссертацияси автореферати. - Тошкент, 2017. - 66 б.

7. Латинин Б.А. Вопросы ирригации и орошаемого земледелия древней Ферганы. - Л., 1962. - 31 с.

8. Мухамедов А.К. Мелиорация асослари. Тошкент, 2008. - 1296.
9. Солиев А. Назаров М. Ўзбекистон қишлоқлари (Қишлоқ жойлар географияси). - T.: Fan va texnologiya, 2009. - 2126.

10. Султонов Т.3., Бегматов И.А. Ўзбекистонда суғориш тизимларининг ривожланиш тарихи//Irrigation and Melioration: Vol. 2016. - Б. 8-11.

11. Толстов С.П. Аревний Хорезм. Опыт историко-археологического исследования. - М., 1948. - 440 с.

12. Толстов С.П. Қадимги Хоразм маданиятини излаб. - Т.: Фан, 1964. - 441 6.

13. Толстов С.П. По древним дельтам Окса и Яксарта. - М., 1962. - 321 с.

14. Толстов С.П. По следам древне Хорезмийской цивилизации. - М., - Л., 1948. -328 c.

15. Alokhunov A.A. Thoughts In Regard To Location Of Pastoralists Monuments In Fergana Valley. European Journal of Business \& Social Sciences. (EJBSS), Vol-07, Issue-10 July 2019. Switzerland. - P. 37-48.

16. Alokhunov A.A. The issue of studiedness of ancient Fergana in chinese manuscripts. EPRA International Journal of Multidisciplinary Research (IJMR), Vol-6, Issue-1 January 2020. India. - P. 212-215.

17. Алохунов А.А. Фарғона водийсининг Қайроққум маданияти ёдгорликлари. ФарДУ Илмий Хабарлар, 5/2017. - Б. 91-92.

18. Алохунов А.А. Фарғона қадимги Шарқ илк дехқон жамоаларининг миграциялари даврида. ФарДУ Илмий Хабарлар, 2/2019. - Б. 60-63.

19. Yuldashev S.B. Ferghana in the VII century: It's development as a powerful state and its collapse // History Reseach Journal. 2019 vol. 5. Issue 6. - P. 2952-2964. 
20. Yuldashev S.B. Samanids of Ferghana // International journal for social studies. 2020. vol. 6. Issue 01. - P. 120-135.

21. Yuldashev S.B. The impact of the Aksu battle on Ferghana // ERPA International Journal of Research and Development. 2020. Vol. 5 (8). P. 60-64. DOI: https://doi.org/10.36713/epra4917

22. Yuldashev S.B. Early arab invasions of Fergana // «Евразийский Союз Ученых» научный журнал. - Москва, - 2020. - № 8 (77/4). - P. 31-35. 